Nudging Investors Big and Small Toward Better Decisions

Philip W. S. Newall

University of Stirling

\author{
Bradley C. Love \\ University College London
}

Investors significantly reduce their future returns by selecting mutual funds with higher fees, allured by higher past returns that do not predict future performance. This suboptimal behavior, which can roughly halve an investor's retirement savings, is driven by two psychological factors. One factor is difficulty comprehending rate information, which is critical given that mutual fund fees and returns are typically communicated in percentages. A second factor is devaluing small differences in returns or fees (i.e., a peanuts effect). These two factors interact such that large investors benefit when fees are stated in currency (as opposed to percentages), whereas small investors benefit from returns stated in currency. These striking results suggest behavioral interventions that are tailored specifically for small and large investors.

This article may not exactly replicate the final version published in the APA journal. It is not the copy of record. Accepted for publication in Decision published by American Psychological Association: https://doi.org/10.1037/dec0000036 


\section{Nudging Investors Big and Small Toward Better Decisions}

Choosing a proper investment strategy is key to financial health, particularly in an era where commonplace defined-contribution retirement plans require individual investors to make their own portfolio allocation decisions (Zelinsky, 2004). Unfortunately, most non-specialists have a very poor understanding of the basics of investing in mutual funds, and, as a result, they adopt strategies that cause their returns to suffer (Barber, Odean, \& Zheng, 2005; Elton, Gruber, \& Busse, 2004) and even jeopardize the possibility of their enjoying a comfortable retirement. In this contribution, we address how these negative consequences resulting from lack of knowledge can be ameliorated or exacerbated by how information is conveyed to investors.

Mutual fund investors must weigh a number of factors when making an investment decision, including past returns, management fees, fund manager, and risk (Wilcox, 2003). Many investors select mutual funds on the basis of high past returns (Barber et al., 2005; Choi, Laibson, \& Madrian, 2010; Navone, 2012; Sirri \& Tufano, 1998; Wilcox, 2003), yet the evidence indicates that this is a poor strategy (Carhart, 1997), because differences in past performance between mutual funds with similar investment strategies are largely attributable to factors that do not predict future performance. For example, due to market cycles and fluctuations, identical funds originated on different dates can have dramatically different past returns. Nevertheless, investors are allured by past returns and often purchase high-cost funds that are unlikely to beat low-cost alternatives. Instead, better returns (after fees) can be attained by selecting mutual funds with low management fees (Bogle, 1999; Gruber, 1996; Malkiel, 1999), because after-fee average future performance is reduced approximately one-for-one by 
increases in fees (Sharpe, 1991). Unfortunately, many investors either lack this key knowledge regarding fees or fail to act on it because of how investment decisions are framed.

The US mutual fund industry had $\$ 14.7$ trillion invested at the end of 2012 , at an average expense ratio of 0.99\% a year (Investment_Company_Institute, 2013), even though mutual funds with expenses as low as $0.05 \%$ a year are available. Thus, there is great potential for improving the welfare of typical investors, such as those saving for retirement. Even small increases in the weight given to fees, relative to past returns, can lead to significant improvements in investor welfare from a behavior change perspective (Thaler \& Sunstein, 2009).

To offer a brief numerical example of the importance of choosing low-fee funds, the US stock market produced a total average return of $10.9 \%$ between 1970-2013. At zero cost, this would have seen a $\$ 1,000$ investment grow to more than $\$ 94,839$. Although all mutual funds charge fees, funds with expenses as low as $0.05 \%$ now exist (for example Admiral shares of the Vanguard S\&P 500 Index fund). This fee would reduce final wealth to $\$ 92,976$. A $1 \%$ annual fee, however, is enough to reduce the final investment balance to $\$ 63,665$ - a reduction in final wealth of $\$ 31,174$. A high $1.72 \%$ fee fund (approximately the most expensive in the US market) would reduce the final balance further, to $\$ 47,676$, which is roughly half the return of the lowcost fund that is the same product for all intents and purposes. Fees, which are typically assessed as an annual percentage of the current investment size, can clearly reduce an investor's returns significantly over the long haul.

Rather than simple financial illiteracy, one possibility is that investors make poor decisions in part because of idiosyncrasies in how humans process numeric information. Indeed, these basic psychological factors may help explain why investors favor higher-cost funds. If so, 
then a better understanding of these factors may spur the development of effective interventions to improve financial decision making and financial health. In what follows, we identify two interacting psychological factors that serve to shape suboptimal investment decisions, and show how the influence of these factors can be ameliorated or exaggerated as a result of the way in which information is presented to investors.

The first psychological factor that we suspect leads to poor investor decision making is a difficulty reasoning effectively when information is presented in a rate or percentage format, as fees and returns in mutual funds typically are (e.g., fees of $1 \%$ a year; $+10 \%$ expected return per year). There is an abundance of evidence that people are poor at reasoning with rate information. For example, shoppers prefer offers in which they get $50 \%$ more of a product for free than an equivalent 33\% price reduction (Chen, Marmorstein, Tsiros, \& Rao, 2012), even though both offers are identical in financial terms. People are no better with fractions. In the early 1980s, a fast food chain discontinued its third-pound of beef burgers because consumers thought the meat patties were smaller than McDonald's quarter pounder as the 4 in $1 / 4$ is greater than the 3 in $1 / 3$ (Green, 2014). In evaluating fuel economy, which is typically expressed as a rate (i.e., miles per gallon; MPG), people make systematic decision errors treating the difference between 10 MPG and $20 \mathrm{MPG}$ vehicles as equivalent to that between $40 \mathrm{MPG}$ and 50MPG vehicles, when in fact the improvement in the first case is $100 \%$ but only $25 \%$ in the second case (Larrick \& Soll, 2008). In general, people seem to reason more effectively when information is communicated in concrete (non-rate) formats (Gigerenzer \& Hoffrage, 1995). In the investment domain, transforming percentage fees to a number format can draw more attention to costs (Choi et al., 2010; Hastings \& Tejeda-Ashton, 2008). 
To illustrate the difficulties that investors might face when dealing with information in percentage format, we asked 1,973 investors across our two experiments the following numerical literacy question:

\section{A stock mutual fund has a return of $+\mathbf{1 0 \%}$ in year one, and a return of $\mathbf{- 1 0 \%}$ in year} two. The mutual fund's final value is:

- More than its initial value [chosen by $20.4 \%$ of investors]

- Equal to its initial value [chosen by $33.9 \%$ of investors]

- Less than its initial value [chosen by $45.7 \%$ of investors]

Less than half $(45.7 \%)$ of the sample arrived at the correct answer, which requires appreciating that the geometric mean, not the arithmetic mean, is the appropriate operation for percentages and other rate information.

The second psychological factor that we suspect leads to poor investor decision making is a downweighting of small costs and returns, sometimes labeled the "peanuts effect" (Weber \& Chapman, 2005). People tend to discount the consequences of repeating actions that incur a small cost or lead to a small gain, which can have serious consequences for repeated behaviors such as smoking (Loewenstein, Asch, Friedman, Melichar, \& Volpp, 2012). In investing, the peanuts effect leads to fees or returns in currency units (i.e., presented in dollars as opposed to percentages) that are numerically small being downweighted in the decision process. Percentage information is so poorly understood that it should not be subject to downweighting (e.g., it is unclear to people whether $1 \%$ of a million dollars is sizable).

As we will show, these two psychological factors, poor comprehension of rate information and insensitivity to small rewards or costs, interact in surprising ways to shape investors' decisions depending on how much an individual has to invest. When fees are stated in terms of currency (as opposed to percentages; See Figure 1) and return rates are presented as 
percentages, we might expect that smaller investors will be more likely to treat the increased costs of higher-fee funds as inconsequential (i.e., a peanuts effect), whereas cost differences will be salient to large investors in this format. The effect for large investors has previously been established in mutual fund investing (Choi et al., 2010; Hastings \& Tejeda-Ashton, 2008), but the peanuts effect is novel, with small investors expected to make even worse decisions than in the percentage format real-world status quo.

\begin{tabular}{|c|c|}
\hline Fund A factsheet & Fund B factsheet \\
\hline Fee for this size of investment: $\$ 15.00$ per year & Fee for this size of investment: $\$ 10.00$ per year \\
\hline Benchmark: S\&P 500 & Benchmark: S\&P 500 \\
\hline After-Fee Return (Profit): $1.5 \%$ per year & After-Fee Return (Profit): $1.0 \%$ per year" \\
\hline
\end{tabular}

*Past performance does not guarantee future results.

\begin{tabular}{|c|c|}
\hline \multicolumn{1}{|c|}{ Fund.A factsheet } & Eund B factsheet \\
\hline \multirow{2}{*}{\begin{tabular}{|c|} 
Fee for this size of investment: 1.5\% per year \\
Benchmark: S\&P 500
\end{tabular}} & Fee for this size of investment: 1.0\% per year \\
\hline $\begin{array}{c}\text { After-Fee Return (Profit) for this size of investment: } \\
\text { \$15,00 per year }\end{array}$ & $\begin{array}{c}\text { After-Fee Return (Profit) for this size of investment: } \\
\text { \$10.00 per year }\end{array}$ \\
\hline
\end{tabular}

"Past performance does not guarantee future results.

Figure 1: Example stimuli in the $\$ 1,000$ (low-investment amount) conditions of Experiments 1 (panel A) and 2 (panel B). The default, as in the real-world, is to state both fees and returns in percentages. In Experiment 1, fees were either presented in terms of currency or percentages. $\underline{\text { Panel A shows an example where fees are in currency format. Experiment } 2 \text { manipulated the }}$ format (percentage or currency) of returns. Panel B shows expected returns in terms of currency. The opposite pattern can be expected when past performance is stated in currency and fees are in percentage. When past performance phrased in terms of currency, small investors can 
be expected to neglect differences in returns (i.e., a peanuts effect), whereas return differences will now be especially salient to larger investors in this format. In this case, we might expect investors' poor ability to understand the impact of fees stated in percentages to lead large investors to aim for higher returns, whereas smaller investors will be now discount trivial differences in returns and make the "wiser" investment decision in this context.

On the other hand, when both fee and return information is phrased in terms of percentages, we might expect that investor behavior will vary little across investment size simply because information presented in this format tends to be poorly understood and opaque to investors. In summary, large investors should benefit when fees are presented as currency units, but suffer when returns are stated in currency units. Smaller investors should show the opposite pattern. To foreshadow our results, we observe this three-way interaction.

\section{Experiments}

In Experiments 1 and 2, participants made a single forced choice between a low- and high-fee mutual funds that followed the same investment strategy. The "correct" choice is the low-fee fund as fees are more predictive of future returns than past performance (Carhart, 1997). For ease of comparing effect size between-experiments, the funds had identical fee/past performance trade-offs (a fund with $1 \%$ on both fees and past performance, and a fund with $1.5 \%$ fees and past performance). Usually past performance will range on a much larger scale than fees, confounding potential explanations of why investors do not minimize fees. The high-fee fund always had higher past performance, which could be the case if S\&P 500 index funds were initiated on different start dates (Choi et al., 2010). Experiments 1 and 2 each had four conditions 
resulting from crossing fund size ( $\$ 1,000$ vs. $\$ 1,000,000)$ and format (currency or percentage) of either the fees (Experiment 1) or the expected returns (Experiment 2).

\section{Method}

US-based investors were recruited using Amazon Mechanical Turk, a paid online crowdsourcing platform, which is an effective method for recruiting demographically diverse samples (Buhrmester, Kwang, \& Gosling, 2011) and has been shown to yield results consistent with decision making studies in the laboratory (Crump, McDonnell, \& Gureckis, 2013). Participants were screened based on the presence of household investments, defined as any stocks, bonds, or mutual funds in an investment or defined-contribution account. Participants in Experiments $1(n=1,010)$ and $2(n=963)$ had similar demographic profiles that were typical of US investors (see Table 1). The data-collection target was set in advance at $n=1,000$, in order to have 250 participants on average per-cell and achieve $99 \%$ for a medium effect size. No variables or conditions were omitted in the analyses. 
Table 1: A comparison of participants across the two experiments.

\begin{tabular}{lcc}
\hline Participant Characteristics & Experiment 1 & Experiment 2 \\
\hline Age & 30.9 & 31.9 \\
$\quad$ Mean & 10.1 & 10.8 \\
$\quad$ Standard deviation & $18-79$ & $18-74$ \\
$\quad$ Range & & \\
Education & $0.8 \%$ & $0.6 \%$ \\
$\quad$ Some high school & $6.9 \%$ & $10.2 \%$ \\
$\quad$ High school graduate & $39.1 \%$ & $37.4 \%$ \\
$\quad$ Some college & $53.2 \%$ & $51.8 \%$ \\
$\quad$ College graduate & & \\
Gender & $33.5 \%$ & $38.9 \%$ \\
$\quad$ Female & $66.5 \%$ & $61.1 \%$ \\
$\quad$ Male & & \\
Percentages question & $47.8 \%$ & $43.5 \%$ \\
$\quad$ Less than & $32.0 \%$ & $35.9 \%$ \\
Equal to & $20.2 \%$ & $20.6 \%$ \\
$\quad$ Greater than & & \\
Portfolio size & $45.1 \%$ & $57.9 \%$ \\
$\quad<\$ 10,000$ & $40.4 \%$ & $28.3 \%$ \\
$\quad \geq 10,000<\$ 100,000$ & $14.5 \%$ & $13.8 \%$ \\
$\geq \$ 100,000$ & &
\end{tabular}

In all conditions and across both experiments, participants were shown a short description of two hypothetical mutual funds, labeled Fund A and Fund B, before being asked to choose their preferred fund:

\footnotetext{
Stock mutual funds combine the money from many investors to buy a variety of stocks. This makes it easier for investors to have diversified portfolios. Mutual funds charge fees in return for this service. Mutual funds are devised to follow some benchmark of stocks, such as the S\&P 500 which is the weighted average return of the 500 largest US stocks.
}

Your task is to invest $[\$ 1,000 / \$ 1,000,000]$ in one of the two mutual funds below. Both funds follow a similar investment strategy, but were launched at different times around a year ago.

Participants who respond with the better answer will be entered into a $\$ 10$ lottery.

Below this description of the two mutual funds, a table was shown describing the fees and past returns for the two funds (see Figure 1). Participants chose between a low-fee fund, with 
fees of $1 \%$ a year and after-fee returns of $1 \%$, and a high-fee fund with both fees and after-fee returns of $1.5 \%$ a year. Labeling of Fund $\mathrm{A} / \mathrm{B}$ as the low-fee fund was counterbalanced in each condition.

The default (as in the real-world) is to show both fees and returns in percentage format to participants. In Experiment 1, whether fees were shown in percentages or currency was varied across participants, whereas in Experiment 2 the format was varied for returns. As motivated above, small investors $(\$ 1,000)$ should make worse decisions when fees are presented in currency units, but benefit when returns are stated in currency units. Large investors $(\$ 1,000,000)$ should show the opposite pattern.

\section{$\underline{\text { Results }}$}

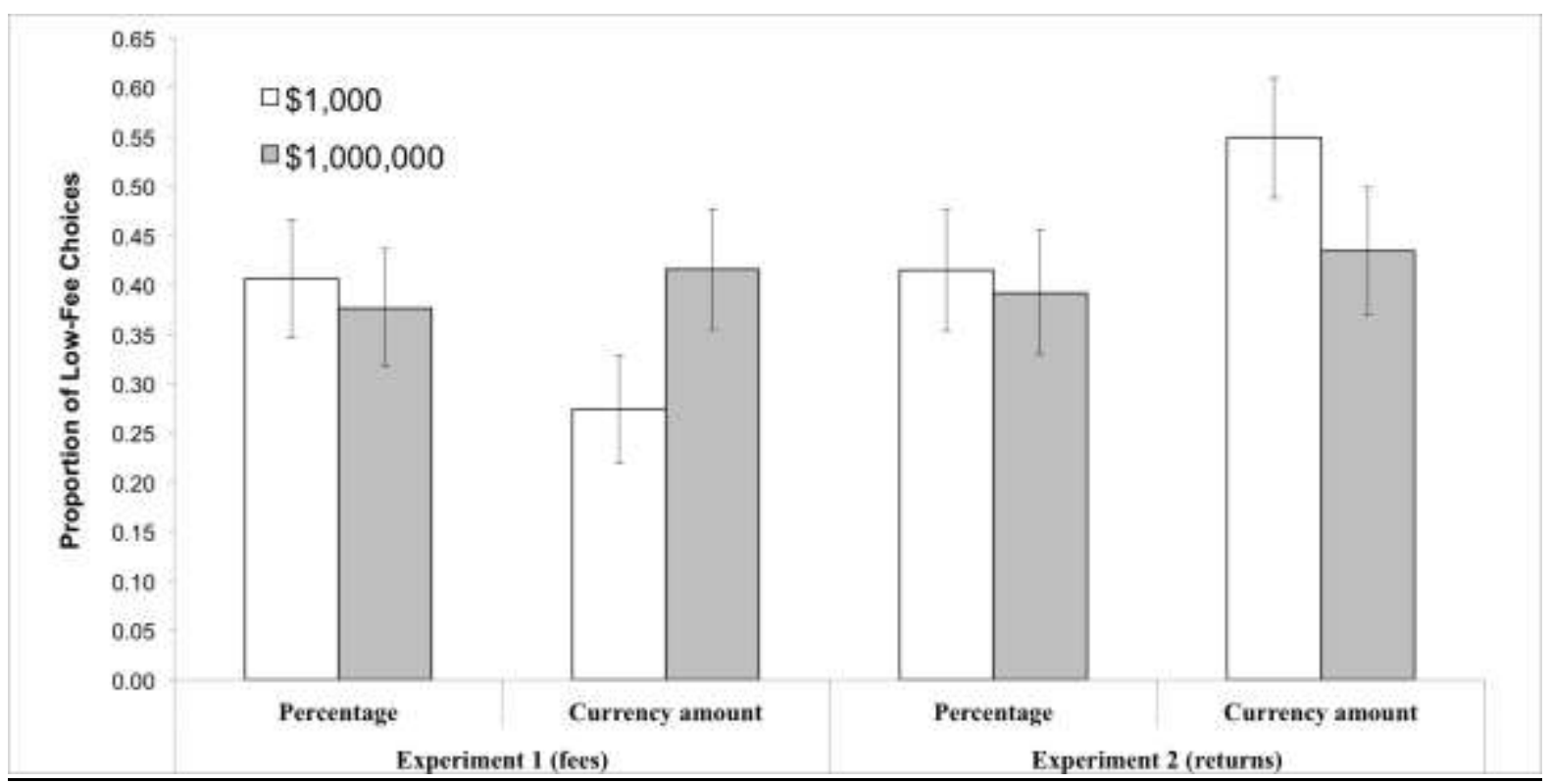


Figure 2: Results from both experiments. In Experiment 1, fees were either in percentages or currency. In Experiment 2, the format of returns was manipulated. Error bars are $95 \%$ confidence intervals of the mean.

Experiment 1's data were subjected to a logistic regression with fund choice (lowfee/high-fee) as the binary dependent variable, and fee framing (percentage or currency), portfolio size ( $\$ 1,000$ or $\$ 1,000,000)$, and their interaction as independent variables. As predicted, there was a significant interaction (see Figure 2) between fee framing and portfolio size, $\chi^{2}(1,1010)=8.29, \mathrm{p}=.004$. The interaction was consistent with the two hypothesized psychological factors: a peanuts effects in which small investors were more likely to choose the high-cost fund (only $\$ 5$ more on a $\$ 1,000$ investment) than were large investors, $\chi^{2}(1,502)=$ $11.11, \mathrm{p}=.001$, as well as a poor understanding of rate information reflected in no significant difference in preference when all information was in percentages, $\chi^{2}(1,508)=0.46, \mathrm{p}=.499$.

Experiment 2 was the same as Experiment 1, except that fees were always stated in terms of percentages and instead the format of returns was either in percentages or currency format (see Figure 1). Although not significant, format and investment amount interacted in the predicted direction, $\chi^{2}(1,963)=1.97, \mathrm{p}=.161$. Following the two hypothesized psychological factors, there was again no difference in choices for the percentage conditions, $\chi^{2}(1,478)=0.25$, $\mathrm{p}=.618$, but a significant effect (this time in the opposite direction, as predicted) for the currency conditions, $\chi^{2}(1,485)=6.30, \mathrm{p}=.012$.

The effect of format was strikingly different across Experiments 1 (fees) and 2 (returns). One way to quantify these contrasting patterns is to evaluate the three-way interaction (study $\mathrm{x}$ format $\mathrm{x}$ investment size) across studies, $\chi^{2}(1,1973)=9.19, \mathrm{p}=.002$. Although our focus was on 
this interaction, it is noteworthy that across conditions only $40.8 \%$ of investors chose the low-fee fund (i.e., made a correct investment decision) with only small investors choosing the low-fee fund at chance levels when returns were presented in terms of currency (see Figure 2).

Both psychological factors were strongly manifested in our results. Across studies, response rates for the percentage conditions were remarkably flat across investment size, consistent with a poor understanding of rate information. The second psychological factor, a tendency to discount small returns and fees (i.e., a peanuts effect) was robust: small investors went from choosing the low-fee fund only $27.4 \%$ of the time when fees were stated in terms of currency to $54.9 \%$ of the time when returns were stated in terms of currency. This is a huge framing effect for economically identical choices.

\section{Discussion}

Improving the quality of investors' decisions is a goal with important economic consequences. Previous work has shown that mutual fund investors may benefit from having fees reframed in terms of currency (Choi et al., 2010; Hastings \& Tejeda-Ashton, 2008). The present study adds a key contribution to this result: it is only beneficial for large investors to have fees framed in terms of currency. For small investors a peanuts effect leads to even more returns chasing than in the percentage real-world status quo. Small investors can be nudged toward greater fee-sensitivity, however, if the peanuts effect is instead used to reduce the salience of past returns. Nudges tailored to an individual investor's situation are capable of benefiting investors large or small.

Investors' preference for maximizing past returns over minimizing fees remains an outstanding puzzle in financial behavior. Experiments on slow-moving time-series show that 
participants are unlikely to learn that high past returns do not predict high future performance by themselves (Beshears, Choi, Fuster, Laibson \& Madrian, 2013). Successful heuristics from other domains may hurt mutual fund investors. Since in the real-world past returns tend to vary over a larger scale than fees, any investor who weighs the two cues equally will tend to buy mutual funds with high past returns. The present experiments add an important qualification. Even when choosing between two funds with identical past return/fees trade-offs, $59.2 \%$ of investors chose to maximize past returns. The only condition where past returns and fees were given equal weight was when past returns were subjected to the peanuts effect.

The magnitude of investors' mistakes, and the resultant economic losses, means that no single policy is likely to be sufficient. Experiments have manipulated the mandated disclosure statement, "past performance does not guarantee future results," which is clearly insufficient to prevent investors from purchasing funds with high past returns (as shown by its inclusion in the present experiments), with stronger statements encouraging investors to minimize fees (Fisch \& Wilkinson-Ryan, 2013; Mercer, Palmiter \& Taha, 2010). These interventions increase feesensitivity, but do not prevent investors from chasing high past returns. In this light, our work suggests that manipulating the salience of fees or past returns, depending on the investor's situation, may complement stronger disclosure statements.

A longstanding assumption in economics is that investor biases must be due to a lack of access to financial education, or low levels of financial literacy (Lusardi \& Mitchell, 2011). However, numerous costly financial education programs have been initiated with remarkably few positive results (Willis, 2011). A recent meta-analysis found that financial education interventions have almost no impact on financial behavior (Fernandes, Lynch \& Netemeyer, 
2014). This suggests that nudges may be more cost-effective than education at changing financial behavior.

Real-world investing is more complex than the one-shot task presented to investors in our studies. Many real-world investing scenarios are complicated by advisors who may be incentivized to sell high-fee products, which may lead to smaller effect sizes if these interventions were used in the field. Investors may for example rely on heuristics such as "buy what your advisor recommends" (Monti, Boero, Berg, Gigerenzer \& Martignon, 2012). Encouraging people to seek finance advice and regulating the nature of this advice may prove ineffective in improving investor decision-making because financial advisors often reinforce the biases of their clients (Mullainathan, Noeth \& Schoar, 2012) and many investors prefer to manage their accounts personally, and are likely to do so poorly (Barber \& Odean, 2000).

One implication of our results is that a one-size-fits-all policy might not be effective as small and large investors may react differently to interventions. Although it would seem reasonable to move away from presenting information in poorly understood percentages and to instead adopt currency formats, in some cases, such as small investors considering fees and large investors considering expected returns, this change should worsen financial decision making. Thus, any "nudges" undertaken need to consider the audience.

Finally, one challenge facing many societies is growing wealth inequality (Piketty, 2014) which is a politically contentious and potentially destabilizing issue. Although smarter investing decisions alone will not fully address this issue, choosing low-cost investments could by itself double the retirement savings of some middle-class investors. Given the potential benefit for individuals and society, exploring interventions based on the current findings is warranted. 
Although these interventions are unlikely to be voluntarily enacted by the industry, they could be introduced in a package of behaviorally-informed regulatory measures. The Financial Conduct Authority in the UK has begun exploring nudges and other information disclosures to improve investor welfare, and other financial regulators may soon follow (Erta, Hunt, Iscenko \& Brambley, 2013). 


\section{References}

Barber, B. M., \& Odean, T. (2000). Trading is hazardous to your wealth: The common stock investment performance of individual investors. Journal of Finance, 55(2), 773-806.

Barber, B. M., Odean, T., \& Zheng, L. (2005). Out of sight, out of mind: The effects of expenses on mutual fund flows. Journal of Business, 78(6), 2095-2119. doi: Doi 10.1086/497042

Beshears, J., Choi, J. J., Fuster, A., Laibson, D., \& Madrian, B. C. (2013). What goes up must come down? Experimental evidence on intuitive forecasting. American Economic Review, 103(3), 570-74.

Bogle, J. C. (1999). Common sense on mutual funds : new imperatives for the intelligent investor. New York ; Chichester: John Wiley.

Buhrmester, M., Kwang, T., \& Gosling, S. D. (2011). Amazon's Mechanical Turk: A New Source of Inexpensive, Yet High-Quality, Data? Perspectives on Psychological Science, 6(1), 3-5. doi: Doi 10.1177/1745691610393980

Carhart, M. M. (1997). On persistence in mutual fund performance. Journal of Finance, 52(1), 57-82. doi: Doi 10.2307/2329556

Chen, H., Marmorstein, H., Tsiros, M., \& Rao, A. R. (2012). When More Is Less: The Impact of Base Value Neglect on Consumer Preferences for Bonus Packs over Price Discounts. Journal of Marketing, 76(4), 64-77.

Choi, J. J., Laibson, D., \& Madrian, B. C. (2010). Why Does the Law of One Price Fail? An Experiment on Index Mutual Funds. Review of Financial Studies, 23(4), 1405-1432. doi: Doi 10.1093/Rfs/Hhp097

Crump, M. J., McDonnell, J. V., \& Gureckis, T. M. (2013). Evaluating Amazon's Mechanical Turk as a tool for experimental behavioral research. PLoS One, 8(3), e57410. doi: 10.1371/journal.pone.0057410

Elton, E. J., Gruber, M. J., \& Busse, J. A. (2004). Are investors rational? Choices among index funds. Journal of Finance, 59(1), 261-288. doi: Doi 10.1111/J.1540-6261.2004.00633.X

Erta, K., Hunt, S., Iscenko, Z., Brambley, W. (2013). Applying behavioural economics at the Financial Conduct Authority. FCA Occasional Paper No.1.

Fernandes, Daniel, John G. Lynch, Jr., and Richard G. Netemeyer (2014). Financial literacy, financial education, and downstream financial behaviors. Management Science, 60 (8), 1861-1883.

Fisch, J. E., \& Wilkinson-Ryan, T. (2013). Why do retail investors make costly mistakes? An experiment on mutual fund choice (No. 2013/23). Center for Financial Studies (CFS).Gigerenzer, G., \& Hoffrage, U. (1995). How to improve Bayesian reasoning without instruction: Frequency formats. Psychological review, 102, 684-704.

Green, E. (2014, July, 23, 2014). Why Do Americans Stink at Math? The New York Times Magazine.

Gruber, M. J. (1996). Another puzzle: The growth in actively managed mutual funds. Journal of Finance, 51(3), 1044-1044.

Hastings, J. S., \& Tejeda-Ashton, L. (2008). Financial literacy, information, and demand elasticity: Survey and experimental evidence from Mexico National Bureau of Economic Research, w14538. 
Investment_Company_Institute. (2013). Investment company fact book: A review of trends and activities in the U.S. investment company industry. ICI factbook.

Larrick, R. P., \& Soll, J. B. (2008). Economics - The MPG illusion. Science, 320(5883), 15931594. doi: Doi 10.1126/Science. 1154983

Loewenstein, G., Asch, D. A., Friedman, J. Y., Melichar, L. A., \& Volpp, K. G. (2012). Can behavioural economics make us healthier? British Medical Journal, 344. doi: DOI 10.1136/bmj.e3482

Lusardi, A., \& Mitchell, O. S. (2011). Financial literacy and planning: Implications for retirement wellbeing (No. w17078). National Bureau of Economic Research.

Malkiel, B. G. (1999). Random Walk Down Wall Street. New York: Norton.

Mercer, M., Palmiter, A. R., \& Taha, A. E. (2010). Worthless warnings? Testing the effectiveness of disclaimers in mutual fund advertisements. Journal of Empirical Legal Studies, 7(3), 429-459.

Monti, M., Boero, R., Berg, N., Gigerenzer, G., \& Martignon, L. (2012). How do common investors behave? Information search and portfolio choice among bank customers and university students. Mind \& Society, 11(2), 203-233.

Mullainathan, S., Noeth, M., \& Schoar, A. (2012). The Market for Financial Advice: An Audit Study. NBER Working Paper, (w17929).

Navone, M. (2012). Investors' distraction and strategic repricing decisions. Journal of Banking \& Finance, 36(5), 1291-1303. doi: Doi 10.1016/J.Jbankfin.2011.11.018

Piketty, T. (2014). Capital in the Twenty-First century. New York: Harvard University Press.

Sharpe, W. F. (1991). The Arithmetic of Active Management. The Financial Analysts' Journal, 47(1), 7-9.

Sirri, E. R., \& Tufano, P. (1998). Costly search and mutual fund flows. Journal of Finance, 53(5), 1589-1622. doi: Doi 10.1111/0022-1082.00066

Thaler, R. H., \& Sunstein, C. R. (2009). Nudge : improving decisions about health, wealth and happiness. London: Penguin Books.

Weber, B. J., \& Chapman, G. B. (2005). Playing for peanuts: Why is risk seeking more common for low-stakes gambles? Organizational Behavior and Human Decision Processes, 97(1), 31-46. doi: Doi 10.1016/J.Obhdp.2005.03.001

Wilcox, R. T. (2003). Bargain hunting or star gazing? Investors' preferences for stock mutual funds. Journal of Business, 76(4), 645-663. doi: Doi 10.1086/377034

Willis, L. E. (2011). The financial education fallacy. The American Economic Review, 101(3), 429-434.

Zelinsky, E. A. (2004). The defined contribution paradigm. Yale Law Journal, 114(3), 451-+. doi: Doi 10.2307/4135691 